\title{
Bacterial colonization of seston particles in brackish waters (Ria de Aveiro, Portugal)
}

\author{
M. Adelaide Almeida, Fernanda Alcântara \\ Department of Biology, University of Aveiro, Campo Universitário, P-3800 Aveiro, Portugal
}

\begin{abstract}
The frequency of attached bacteria, as percentage of total bacteria, in estuarine water of the Ria de Aveiro was determined over a seasonal range of temperature, seston, BOD, salinity and water depth. The frequency was inversely related to temperature only in the marine zone of the lagoon. No other associations could be established with environmental factors. The broad spring-summer peak of total bacteria was not apparent in attached bacteria which showed an erratic temporal profile with an average frequency of $9 \%$ (range 1 to $49 \%$ ) of total planktonic bacteria. The bacterial coverage per unit area of particle surface was densest in small particles. The density of coverage decreased sharply to values corresponding to 22,5 and $2 \%$ in particles $>3$ to $10,>10$ to 40 and $>40$ to $140 \mu \mathrm{m}$ in diameter respecitvely compared to the density of coverage of the $>1$ to $3 \mu \mathrm{m}$ size-class. Colonized seston and sediment particles exhibited similar bacterial numbers per particle of each size-class and did not show tidal, spatial or seasonal patterns of variation. It is suggested that bacteria only seldom attach to particles in the water column of this lagoon and that resuspension of bottom sediments is the main factor governing the frequency of colonized particles in surface water
\end{abstract}

\section{INTRODUCTION}

Planktonic bacteria can be either free-living or attached to suspended particles. The frequency of these 2 fractions may vary dramatically from less than $1 \%$ to about $98 \%$ of total bacteria (reviewed by Iriberri et al. 1987). No obvious reason explains this variation although different factors have been associated with high frequencies of the attached state, e.g. water turbidity (Goulder 1977), salinity (Palumbo et al. 1984), temperature, light, turbulence, nutrients (reviewed by Lopez 1980) and the abundance of organically rich seston (Kondratieff \& Simmons 1985). This state can be advantageous in natural environments (Pedròs-Alio \& Brock 1983) and protective against stress (Harvey et al. 1982). Bacterial attachment to particles has been linked with increased capacity for heterotrophic activity (Hanson \& Wiebe 1977) leading to high rates of mineralization (Goulder 1977) and biomass production (Fergusson \& Rublee 1976) and/or to the accumulation of secreted materials (Paerl 1975). Loosdrecht et al. (1990) conclude, however, that the diverse metabolic changes do not always follow a general increase in activity after bacterial adhesion. The importance of the attached state is associated, on the other hand, with the flow of bacterial biomass in the food web as the free-living and the attached bacteria may be predated selectively by different species (Albright et al. 1987, Sibbald \& Albright 1988).

We studied bacterial colonization of particles in the Ria de Aveiro with 2 main objectives: (1) to relate the observed frequency of attached bacteria with a set of environmental variables often mentioned as important in other aquatic ecosystems; (2) to assess the distribution of the bacteria on 4 size-classes of particles in the range $>1$ to $140 \mu \mathrm{m}$ in diameter, this being relevant to their potential contribution to the diet of different predators.

\section{MATERIALS AND METHODS}

Study sites. The Ria de Aveiro, on the western coast of Portugal $\left(8^{\circ} 44^{\prime} \mathrm{W}, 40^{\circ} 39^{\prime} \mathrm{N}\right)$, is a tidal lagoon with an area of $47 \mathrm{~km}^{2}$ connected to the Atlantic by a narrow opening. It exchanges with the sea a volume of water of 25 to $90 \times 10^{6} \mathrm{~m}^{3}$ between tides of 1 to $3 \mathrm{~m}$ 
amplitude (Hall 1982). Several rivers and streams carry fresh water into the lagoon, the River Vouga being the main input. Fig. 1 shows the location of 16 sampling stations, one (P11) in this river. Within the Ria proper we distinguish the Canal de Mira (Stns M1, M2 \& M3), which has almost no industrial activity, from all the other channels which show different degrees of industrial and domestic pollution (P2 to P20). Table 1 summarizes the hydrographical variables and values of labile organic matter (BOD) and seston.

Sampling method. Near-surface water samples used for bacterial counts were collected at about $0.30 \mathrm{~m}$ in sterile glass containers and were immediately fixed in $1.2 \%$ formaldehyde. Sediments were sampled with a Van Veen type dredge. A sediment subsample of about

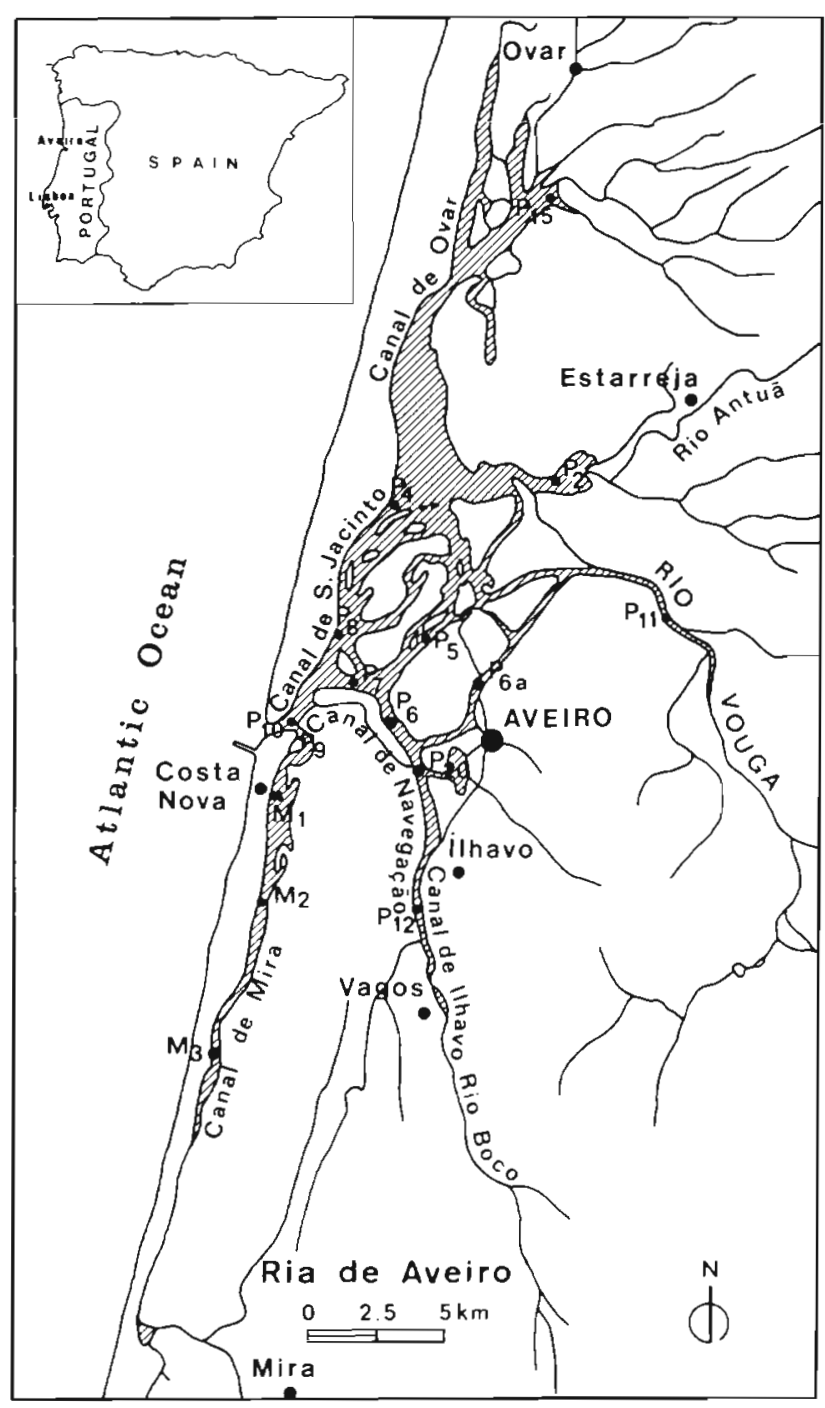

Fig. 1 Location of 16 sampling stations in the Ria de Aveiro, Portugal: in the Canal de Mira (Stns M1, M2, M3); in the mouth of the Ria (Stn P10), in other channels (Stns P2, P4, P5, P6, P7, P8, P9, P12, P15, P20) and in the River Vouga (Stn P11)
$200 \mathrm{~g}$ wet weight, aseptically removed from the undisturbed top layer (about $0.5 \mathrm{~cm}$ thick), was collected into a sterile bottle. For seston dry weight and organic matter determinations, a $5 \mathrm{l}$ sample of surface water was collected in plastic jars. Sampling was usually at high tide during the morning and followed the tidal flux to the different stations. Sampling was every 2 mo at Stns P2 to P20 and monthly at Stns M1 to M3.

Direct bacterial counts. Acridine orange direct counts of bacteria were performed in water samples and dilutions of sediment suspensions according to Hobbie et al. (1977). Three replicates per sample were observed and a minimum of 20 optical fields (or 350 total cells) were counted for each. The number of observed bacteria attached to seston and sediment particles was doubled to account for hidden cells underneath the particles. Epifluorescence observation was performed using a Leitz Laborlux microscope equipped with a 3 -Ploempak system and FITC I2 filters.

Particle frequency. Surface water volumes of $500 \mathrm{ml}$ were taken from the $5 \mathrm{l}$ samples and immediatly frozen at $-20^{\circ} \mathrm{C}$ in polyethylene bottles. Within 1 mo the frozen subsamples were gently melted during $10 \mathrm{~h}$ at room temperature and $100 \mathrm{ml}$ aliquots were freezedried (Dura Dry, FTS Systems Inc.) to obtain a final 5 -fold particle concentration. The concentrated suspensions were analysed for particle size (up to $140 \mu \mathrm{m}$ diameter) and frequency (percentage) of the different particle sizes in a laser light diffraction granulometer (Malvern, $2600 \mathrm{C}$ ) with a $100 \mathrm{~mm}$ focal length cell as described by Brown \& Felton (1985) and Rebola et al. (1988). Distilled water filtered through $0.2 \mu \mathrm{m}$ pore polycarbonate filters was used to calibrate the granulometer and for particle-suspension dilutions. Sample dilution, if necessary, was performed under gentle magnetic stirring for $5 \mathrm{~min}$

Seston dry weight and organic matter content. Subsamples of $500 \mathrm{ml}$ of water were filtered, in triplicate, through glass fibre filters (Schleicher \& Schuell, no. 6). The filters were dried at $60^{\circ} \mathrm{C}$ to constant weight. The same filters were used for organic matter determinations by combustion at $550^{\circ} \mathrm{C}$ for $4 \mathrm{~h}$ (Rodier 1971).

Hydrographical characteristics. Salinity and temperature were determined with a WTW LF196 conductivity meter and dissolved oxygen with a WTW OXI 96 oxygen meter. Current Meter (Braystoke) determinations of maximum water velocity were done by Silva (1989).

Biological oxygen demand (BOD). Oxygen was titrated by the modified Winkler method (Strickland \& Parsons 1972) shortly after sampling and after 5 d incubation in the dark at $20^{\circ} \mathrm{C}$. Titrations on three $50 \mathrm{mI}$ water volumes taken from the same Winkler bottle were averaged for the determination of oxygen consumption. 
Table 1 Water characteristics at the sampled stations (1989 to 1990). Mean, standard deviation and range values (in parentheses) at high tide, and maximum water velocity

\begin{tabular}{|c|c|c|c|c|c|c|c|}
\hline Station & $\begin{array}{l}\text { Salinity } \\
\left(\mathrm{g} \mathrm{l}^{-1}\right)\end{array}$ & $\begin{array}{c}\text { Dissolved } \mathrm{O}_{2} \\
\left(\mathrm{mg} \mathrm{l}^{-1}\right)\end{array}$ & $\begin{array}{c}\text { Temperature } \\
\left({ }^{\circ} \mathrm{C}\right)\end{array}$ & $\begin{array}{c}\mathrm{BOD} \\
\left(\mathrm{mg} \mathrm{l}^{-1}\right)\end{array}$ & $\begin{array}{c}\text { Seston } \\
\left(\mathrm{mg} \mathrm{l}^{-1}\right)\end{array}$ & $\begin{array}{l}\text { Depth } \\
(\mathrm{m})\end{array}$ & $\begin{array}{c}\text { Water vel. } \\
\left(\mathrm{cm} \mathrm{s}^{-1}\right)\end{array}$ \\
\hline P2 & $\begin{array}{l}25.8 \pm 9.6 \\
(8.8-36.2)\end{array}$ & $\begin{array}{c}6.8 \pm 1.7 \\
(4.1-9.7)\end{array}$ & $\begin{array}{c}17.5 \pm 5.0 \\
(18.4-24.6)\end{array}$ & $\begin{array}{c}1.6 \pm 0.8 \\
(0.4-3.1)\end{array}$ & $\begin{array}{r}25.2 \pm 47.8 \\
(5-176)\end{array}$ & $0.5-2.0$ & 72.7 \\
\hline $\mathrm{P} 4$ & $\begin{array}{l}32.2 \pm 4.0 \\
(26.7-35.8)\end{array}$ & $\begin{array}{c}8.5 \pm 1.5 \\
(7.7-10.6)\end{array}$ & $\begin{array}{c}18.4 \pm 3.3 \\
(12.6-21.8)\end{array}$ & $\begin{array}{c}0.8 \pm 0.4 \\
(0.3-1.3\}\end{array}$ & $\begin{array}{r}6.2 \pm 2.3 \\
(3-10)\end{array}$ & $1.0-3.0$ & - \\
\hline P5 & $\begin{array}{l}31.2 \pm 9.6 \\
(7.3-35.8)\end{array}$ & $\begin{array}{c}7.9 \pm 1.2 \\
(4.8-9.6)\end{array}$ & $\begin{array}{c}16.4 \pm 1.6 \\
(13.4-18.4)\end{array}$ & $\begin{array}{c}1.3 \pm 1.5 \\
(0.3-4.7)\end{array}$ & $\begin{array}{r}7.2 \pm 4.5 \\
(2-16)\end{array}$ & $2.0-4.0$ & - \\
\hline P6 & $\begin{array}{c}33.4 \pm 3.2 \\
(26.0-35.8)\end{array}$ & $\begin{array}{c}7.7 \pm 1.0 \\
(6.5-9.5)\end{array}$ & $\begin{array}{c}16.4 \pm 1.7 \\
(13.7-18.5)\end{array}$ & $\begin{array}{c}1.4 \pm 1.1 \\
(0.0-3.2)\end{array}$ & $\begin{array}{r}5.0 \pm 2.9 \\
(2-10)\end{array}$ & $4.0-6.0$ & - \\
\hline $\mathrm{P} 6 \mathrm{a}$ & $\begin{array}{c}32.1 \pm 3.3 \\
(27.0-35.7)\end{array}$ & $\begin{array}{c}7.1 \pm 0.8 \\
(5.7-8.6)\end{array}$ & $\begin{array}{c}17.0 \pm 2.9 \\
(12.1-21.2)\end{array}$ & $\begin{array}{c}1.3 \pm 0.7 \\
(0.0-2.2)\end{array}$ & $\begin{array}{r}6.6 \pm 3.5 \\
(3-16)\end{array}$ & $3.0-5.0$ & 74.3 \\
\hline P7 & $\begin{array}{c}35.0 \pm 1.5 \\
(30.8-35.8)\end{array}$ & $\begin{array}{c}8.2 \pm 0.6 \\
(6.9-9.0)\end{array}$ & $\begin{array}{c}16.4 \pm 1.3 \\
(13.6-18.1)\end{array}$ & $\begin{array}{c}1.1 \pm 0.8 \\
(0.0-2.7)\end{array}$ & $\begin{array}{c}8.4 \pm 5.8 \\
(2-17)\end{array}$ & $9.0-11.0$ & - \\
\hline P8 & $\begin{array}{c}34.8 \pm 1.1 \\
(32.5-35.8)\end{array}$ & $\begin{array}{c}8.5 \pm 0.7 \\
(6.8-9.2)\end{array}$ & $\begin{array}{c}16.2 \pm 1.5 \\
(13.6-18.1)\end{array}$ & $\begin{array}{c}1.0 \pm 0.6 \\
(0.1-1.9)\end{array}$ & $\begin{array}{c}11.0 \pm 10.7 \\
(2-31)\end{array}$ & $8.0-10.0$ & - \\
\hline P9 & $\begin{array}{c}35.0 \pm 1.2 \\
(31.4-35.8)\end{array}$ & $\begin{array}{c}8.4 \pm 0.9 \\
(7.0-10.1)\end{array}$ & $\begin{array}{c}16.2 \pm 1.5 \\
(13.6-18.0)\end{array}$ & $\begin{array}{c}1.4 \pm 1.5 \\
(0.0-5.2)\end{array}$ & $\begin{array}{c}11.0 \pm 11.6 \\
(1-41)\end{array}$ & $5.0-7.0$ & - \\
\hline P10 & $\begin{array}{c}35.4 \pm 0.4 \\
(34.4-35.9)\end{array}$ & $\begin{array}{c}8.8 \pm 0.9 \\
(7.7-10.3)\end{array}$ & $\begin{array}{c}16.1 \pm 1.5 \\
(13.6-18.0)\end{array}$ & $\begin{array}{c}1.0 \pm 0.7 \\
(0.1-1.9)\end{array}$ & $\begin{array}{c}14.0 \pm 16.2 \\
(2-62)\end{array}$ & $11.0-13.0$ & 187.1 \\
\hline P11 & $\begin{array}{c}<2.0 \pm 0.0 \\
(<2.0-0.0)\end{array}$ & $\begin{array}{c}4.9 \pm 2.8 \\
(1.0-8.5)\end{array}$ & $\begin{array}{l}17.6 \pm 6.2 \\
(8.0-27.6)\end{array}$ & $\begin{array}{l}3.9 \pm 3.6 \\
(0.3-10.1)\end{array}$ & $\begin{array}{r}10.4 \pm 4.8 \\
(4-22)\end{array}$ & $0.5-2.5$ & 96.2 \\
\hline P12 & $\begin{array}{c}28.4 \pm 6.8 \\
(17.0-36.0)\end{array}$ & $\begin{array}{c}6.5 \pm 1.6 \\
(4.1-8.7)\end{array}$ & $\begin{array}{l}17.2 \pm 4.5 \\
(9.1-23.8)\end{array}$ & $\begin{array}{c}1.3 \pm 0.9 \\
(0.0-2.5)\end{array}$ & $\begin{array}{c}17.5 \pm 13.5 \\
(4-52)\end{array}$ & $0.8-2.0$ & 118.3 \\
\hline P15 & $\begin{array}{l}23.3 \pm 10.9 \\
(6.9-36.5)\end{array}$ & $\begin{array}{c}7.8+4.2 \\
(0.2-14.5)\end{array}$ & $\begin{array}{l}19.0 \pm 5.4 \\
(9.2-26.3)\end{array}$ & $\begin{array}{c}4.3 \pm 1.5 \\
(2.3-6.6)\end{array}$ & $\begin{array}{r}25.3 \pm 63.2 \\
(3-226)\end{array}$ & $0.5-2.0$ & - \\
\hline P20 & $\begin{array}{c}33.3 \pm 2.5 \\
(30.2-35.8)\end{array}$ & $\begin{array}{c}7.4 \pm 0.7 \\
(6.8-8.7)\end{array}$ & $\begin{array}{c}16.9 \pm 2.0 \\
(13.1-18.5)\end{array}$ & $\begin{array}{c}0.8 \pm 0.7 \\
(0.0-2.8)\end{array}$ & $\begin{array}{r}5.8 \pm 3.1 \\
(2-10)\end{array}$ & $4.0-6.0$ & - \\
\hline M1 & $\begin{array}{c}27.4 \pm 5.6 \\
(14.5-34.5)\end{array}$ & $\begin{array}{l}7.7 \pm 1.0 \\
(6.0-10.5)\end{array}$ & $\begin{array}{c}16.1 \pm 4.1 \\
(10.0-24.0)\end{array}$ & $\begin{array}{c}1.6 \pm 0.5 \\
(0.3-2.8)\end{array}$ & $\begin{array}{c}40.5 \pm 13.4 \\
(7-59)\end{array}$ & $1.5-3.0$ & - \\
\hline M2 & $\begin{array}{l}17.0 \pm 9.9 \\
(1.0-32.0)\end{array}$ & $\begin{array}{c}8.1 \pm 1.5 \\
(4.8-10.2)\end{array}$ & $\begin{array}{l}16.8 \pm 5.8 \\
(9.0-30.0)\end{array}$ & $\begin{array}{c}2.2 \pm 1.1 \\
(0.7-4.5)\end{array}$ & $\begin{array}{c}26.6 \pm 12.8 \\
(3-39)\end{array}$ & $1.5-2.5$ & - \\
\hline M3 & $\begin{array}{c}8.3 \pm 7.7 \\
(0.0-24.5)\end{array}$ & $\begin{array}{c}9.1 \pm 2.4 \\
(5.2-13.0)\end{array}$ & $\begin{array}{c}17.6 \pm 6.0 \\
(10.0-30.0)\end{array}$ & $\begin{array}{c}4.7 \pm 3.2 \\
(0.9-13.4)\end{array}$ & $\begin{array}{c}22.2 \pm 16.9 \\
(3-76)\end{array}$ & $0.3-1.5$ & - \\
\hline
\end{tabular}

Statistical analysis. Correlation coefficients, Student's exact test and Fisher's approached test (Fisz 1963), were applied to evaluate the correlations between the frequency of attached bacteria and different properties of the estuarine water.

\section{RESULTS}

\section{Abundance and frequency of adhered bacteria}

At 16 stations over 2 yr (1989 and 1990), the abundance of adhered bacteria $\left(\mathrm{NB}_{\mathrm{ad}}\right)$ varied within the limits 1 to $20 \times 10^{5}$ cells ml-1, representing 1 to $49 \%$ of the total bacteria number (Table 2). The overall mean of the frequency of adhered bacteria as a percentage of total bacteria $\left(\mathrm{FB}_{\mathrm{ad}}\right)$ was $9 \%$, the annual mean at individual stations varying between 4 and $20 \%$. There was no marked temporal pattern in the fluctuation of $N_{\text {ad }}$ although there was a tendency towards decreased values in summer and autumn. The 2 yr average values of $\mathrm{FB}_{\mathrm{ad}}$ at the contrasting Stns P10 (marine) and $\mathrm{P} 11$ (freshwater) were, respectively, 14 and $7 \%$, values that did not reflect the large difference in salinity. At the other stations, with mean salinities ranging from 8.3 to $35.0 \%$. (Table 1 ), no relationship could be detected between salinity and $\mathrm{NB}_{\mathrm{ad}}$ or $\mathrm{FB}_{\mathrm{ad}}$. Mean annual water temperatures varied from 16 to $19{ }^{\circ} \mathrm{C}$ at different stations (Table 1 ). The frequency of attached bacteria varied inversely (5\% significance level) with temperature at the stations with salinities above $31 \%$. Water depth at the 16 stations (Table 1) varied from $<1$ to $13 \mathrm{~m}$ (Capitania do Porto de Aveiro pers. comm.). There were no correlations between depth or maximum water velocity (Silva 1989) and $\mathrm{NB}_{\mathrm{ad}}$ or $\mathrm{FB}_{\mathrm{ad}}$. 
Table 2. Mean annual values, with range and coefficient of variation, of the abundance and frequency of adhered bacteria in the surface water of the Ria de Aveiro and of the River Vouga at high tide

\begin{tabular}{|c|c|c|c|c|c|c|c|}
\hline \multirow[t]{2}{*}{ Station } & \multirow[t]{2}{*}{ Yea: } & \multicolumn{3}{|c|}{ Number } & \multicolumn{3}{|c|}{ Frequency } \\
\hline & & Mean & Range & $\mathrm{CV}$ & Mean & Range & $\mathrm{CV}$ \\
\hline \multirow[t]{2}{*}{ P2 } & 1989 & 8 & $1-19$ & 103 & 10 & $2-20$ & 82 \\
\hline & 1990 & 3 & $2-5$ & 41 & 4 & $1-11$ & 86 \\
\hline \multirow[t]{2}{*}{ P4 } & 1989 & - & - & - & - & - & - \\
\hline & 1990 & 2 & $1-3$ & 54 & 5 & $1-14$ & 112 \\
\hline \multirow[t]{2}{*}{ P5 } & 1989 & 3 & $1-8$ & 74 & 10 & $5-23$ & 66 \\
\hline & 1990 & 1 & $1-2$ & 39 & 4 & $1-8$ & 67 \\
\hline \multirow[t]{2}{*}{ P6 } & 1989 & 4 & $1-7$ & 59 & 11 & $6-18$ & 49 \\
\hline & 1990 & 2 & $1-3$ & 55 & 5 & $1-9$ & 65 \\
\hline \multirow[t]{2}{*}{ P6a } & 1989 & 6 & $1-16$ & 99 & 12 & $3-25$ & 71 \\
\hline & 1990 & 2 & $1-4$ & 68 & 5 & $2-9$ & 49 \\
\hline \multirow[t]{2}{*}{$\mathrm{P} 7$} & 1989 & 4 & $1-8$ & 90 & 12 & $5-22$ & 67 \\
\hline & 1990 & 2 & $1-5$ & 87 & 5 & $1-7$ & 55 \\
\hline \multirow[t]{2}{*}{ P8 } & 1989 & 7 & $2-20$ & 104 & 16 & $8-34$ & 59 \\
\hline & 1990 & - & - & - & - & - & - \\
\hline \multirow[t]{2}{*}{ P9 } & 1989 & 5 & $1-9$ & 57 & 19 & $1-37$ & 63 \\
\hline & 1990 & 2 & $1-2$ & 37 & 6 & $1-14$ & 73 \\
\hline \multirow[t]{2}{*}{ P10 } & 1989 & 5 & $1-12$ & 89 & 20 & $6-38$ & 56 \\
\hline & 1990 & 2 & $1-3$ & 62 & 8 & $1-17$ & 87 \\
\hline \multirow[t]{2}{*}{ P11 } & 1989 & 3 & $1-5$ & 61 & 8 & $2-20$ & 93 \\
\hline & 1990 & 2 & $1-7$ & 84 & 6 & $1-13$ & 54 \\
\hline \multirow[t]{2}{*}{$\mathrm{P} 12$} & 1989 & 6 & $2-11$ & 69 & 10 & $3-15$ & 51 \\
\hline & 1990 & 7 & $2-16$ & 84 & 12 & $2-39$ & 115 \\
\hline \multirow[t]{2}{*}{ P15 } & 1989 & 2 & $1-5$ & 74 & 5 & $1-15$ & 112 \\
\hline & 1990 & 4 & $1-9$ & 61 & 5 & $3-9$ & 51 \\
\hline \multirow[t]{2}{*}{ P20 } & 1989 & - & - & - & - & - & - \\
\hline & 1990 & 2 & $1-5$ & 70 & 9 & $1-27$ & 122 \\
\hline \multirow[t]{2}{*}{ M1 } & 1989 & 4 & $1-7$ & 47 & 12 & $3-35$ & 64 \\
\hline & 1990 & 3 & $1-11$ & 106 & 7 & $1-22$ & 91 \\
\hline \multirow[t]{2}{*}{ M2 } & 1989 & 7 & $1-17$ & 77 & 12 & $3-32$ & 64 \\
\hline & 1990 & 6 & $2-16$ & 60 & 12 & $2-49$ & 109 \\
\hline \multirow[t]{2}{*}{ M3 } & 1989 & 8 & $1-21$ & 64 & 11 & $1-24$ & 67 \\
\hline & 1990 & 6 & $2-14$ & 79 & 10 & $2-31$ & 108 \\
\hline
\end{tabular}

We tried to relate the frequency of attached bacteria at Stns M1 to M3 with the abundance of seston (dry weight) and with its organic content. Fig. 2 shows these 3 variables from October 1989 to December 1990. Generally, the percentage of organic matter in the particles increased with seston dry weight, indicating the organic nature of seston peaks. In May, however, the organic matter component of the particles increased sharply in spite of the scarcity of seston. The oscillations in $F B_{a d}$ followed neither the fluctuations in the seston dry weight nor those in its organic content.

Along the Canal de Mira the sediments are of medium-grain sands with less than $0.4 \%$ organic matter (Stns M1 \& M2) and silt-clay deposits with $1.8 \%$ organic matter (Stn M3). The total (free and attached) bacteria number (TBN) and $F B_{\overrightarrow{a d}}$ values in surface water and in the top $0.5 \mathrm{~cm}$ layer of the sediments are shown in Table $3 . F B_{\text {ad }}$ in the sediments ranged from 41 to $96 \%$ but showed no clear variation with the type of deposit.

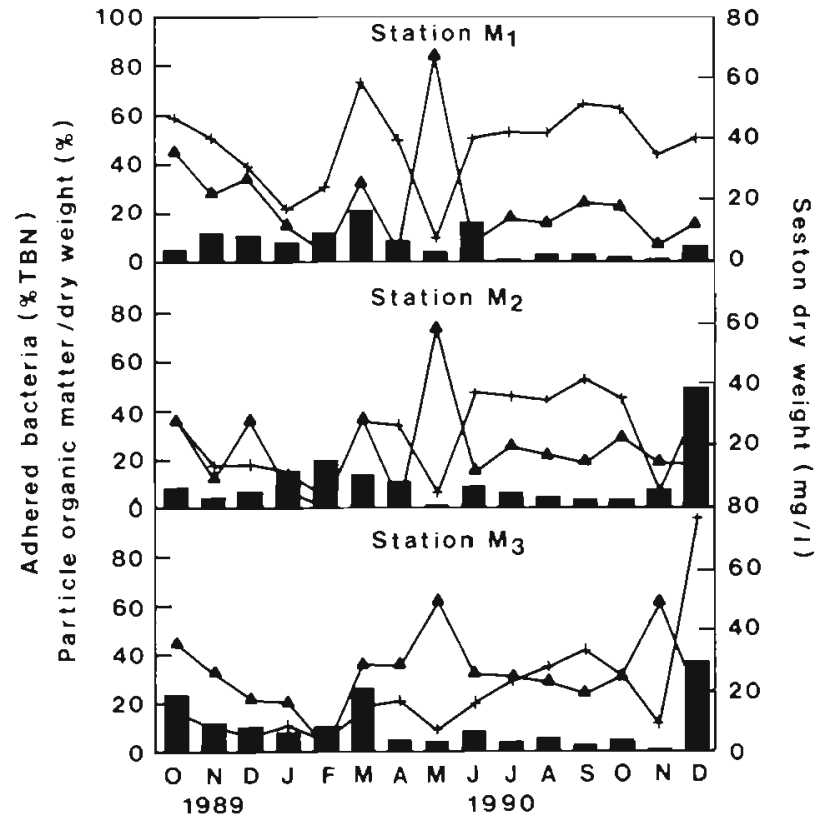

Fig. 2. Comparison of the frequency of adhered bacteria with the abundance of seston and its relative content in organic matter TBN: total number of bacteria in surface water. Bars: $\mathrm{FB}_{\mathrm{ad}}$ (frequency of adhered bacteria); +: seston dry weight; $\Delta$ : percentage of organic matter in seston

The influence of tide on $\mathrm{NB}_{\mathrm{ad}}$ of the surface water was assessed during 6 tidal cycles, 3 at Stn M1 and 3 at Stn M3. The data in Fig. 3 show that only in June did low tide seem to produce, at these 2 stations, a large increase (2- to 3-fold) in $\mathrm{NB}_{\text {ad }}$.

\section{Bacterial colonization of seston and sediment particles}

Fig. 4 shows the variation in the mean number of bacteria on sediment and suspended particles from the 3 stations in the Canal de Mira. Particles were arranged in 4 size-classes, $>1$ to $3,>3$ to $10,>10$ to 40 and $>40$ to $140 \mu \mathrm{m}$. The mean number of bacteria per particle of the 2 first classes was fairly constant both spatially and temporally and was not affected by tide. In surface waters, large particles only rarely supported bacterial cells. The data show that colonized particles $\leq 3 \mu \mathrm{m}$ supported mean numbers of up to 6 bacterial cells, most frequently 2. Irrespectively of tide, the mean number of bacteria per colonized particle in surface water (634 particles) and sediments (2862 particles) was very similar, averaging 2 to 3 cells (particles $>1$ to $3 \mu \mathrm{m}$ ), 5 to 6 cells (particles $>3$ to $10 \mu \mathrm{m}$ ), 13 to 21 cells (particles $>10$ to $40 \mu \mathrm{m}$ ) and 40 to 59 cells (particles $>40$ to $140 \mu \mathrm{m}$ ), as summarized in Table 4 . The largest variation in mean bacterial counts per colonized particle in each size-class corresponded to a factor of 3 in the smaller particles and 
Table 3. Total bacterial number (TBN) and frequency of bacteria adhered to particles ( $\mathrm{FB}_{\mathrm{st}}$, as percentage of TBN) in the top layer of sediments and in the surface water (Canal de Mira, 1988)

\begin{tabular}{|c|c|c|c|c|c|c|c|c|}
\hline \multirow{3}{*}{$\begin{array}{l}\text { Date } \\
\text { (1988) }\end{array}$} & \multicolumn{4}{|c|}{ Surface water } & \multicolumn{4}{|c|}{ Sediment } \\
\hline & \multicolumn{2}{|c|}{ High tide } & \multicolumn{2}{|c|}{ Low tide } & \multicolumn{2}{|c|}{ High tide } & \multicolumn{2}{|c|}{ Low tide } \\
\hline & $\begin{array}{c}\text { TNB } \\
\left(\times 10^{6} \mathrm{ml}^{-1}\right)\end{array}$ & $\begin{array}{l}\mathrm{FB}_{\mathrm{ad}} \\
(\%)\end{array}$ & $\begin{array}{c}\text { TNB } \\
\left(\times 10^{6} \mathrm{ml}^{-1}\right)\end{array}$ & $\begin{array}{c}\mathrm{FB}_{\mathrm{ad}} \\
(\%)\end{array}$ & $\begin{array}{c}\text { TNB } \\
\left(\times 10^{8} \mathrm{gdw}^{-1}\right)\end{array}$ & $\begin{array}{l}\mathrm{FB}_{\mathrm{dd}} \\
(\%)\end{array}$ & $\begin{array}{c}\mathrm{TNB} \\
\left(\times 10^{8} \mathrm{gdw}^{-1}\right)\end{array}$ & $\begin{array}{l}\mathrm{FB}_{\mathrm{ad}} \\
(\%)\end{array}$ \\
\hline \multicolumn{9}{|l|}{ Station M1 } \\
\hline Jun & 6.2 & 12 & 8.4 & 4 & 1.1 & 59 & 0.8 & 60 \\
\hline Jul & 6.6 & 0 & 8.6 & 13 & 0.7 & 82 & 0.3 & 41 \\
\hline Aug & 5.4 & 10 & 10.6 & 21 & 0.4 & 76 & 0.9 & 69 \\
\hline Sep & 6.3 & 3 & 6.6 & 11 & 1.5 & 88 & 0.8 & 77 \\
\hline Oct & 8.3 & 28 & 5.4 & 3 & 0.3 & 65 & 0.3 & 70 \\
\hline Nov & 2.5 & 1 & 4.0 & 17 & 0.8 & 93 & 1.3 & 94 \\
\hline Average & 5.9 & 9 & 7.3 & 12 & 0.8 & 77 & 0.7 & 69 \\
\hline \multicolumn{9}{|l|}{ Station M2 } \\
\hline Jun & 6.7 & 4 & 12.0 & 10 & 1.9 & 74 & 7.5 & 96 \\
\hline Jul & 8.3 & 14 & 8.7 & 22 & 6.3 & 95 & 0.7 & 64 \\
\hline Aug & 8.5 & 12 & 11.0 & 15 & 0.2 & 37 & 11.2 & 88 \\
\hline Sep & 11.0 & 38 & 15.5 & 13 & 1.0 & 77 & 0.3 & 57 \\
\hline Oct & 9.3 & 11 & 9.5 & 8 & 0.6 & 64 & 0.4 & 42 \\
\hline Nov & 5.1 & 8 & 4.9 & 13 & 0.9 & 69 & 0.6 & 79 \\
\hline Average & 8.2 & 15 & 10.3 & 14 & 1.8 & 69 & 3.5 & 71 \\
\hline \multicolumn{9}{|l|}{ Station M3 } \\
\hline Jun & 7.4 & 1 & 1.1 & 4 & 230.8 & 96 & 135.5 & 96 \\
\hline Jul & 6.1 & 8 & 7.5 & 3 & 115.0 & 63 & 158.4 & 66 \\
\hline Aug & 7.0 & 6 & 7.4 & 8 & 75.2 & 72 & 116.7 & 70 \\
\hline Sep & 9.2 & 12 & 19.2 & 68 & 79.5 & 75 & 69.3 & 54 \\
\hline Oct & 5.9 & 20 & 6.9 & 2 & 155.9 & 80 & 91.9 & 80 \\
\hline Nov & 5.6 & 35 & 5.2 & 15 & 98.1 & 83 & 426.0 & 95 \\
\hline Average & 6.9 & 14 & 7.9 & 17 & 125.8 & 78 & 166.3 & 77 \\
\hline
\end{tabular}

Fig. 3. Tidal fluctuations in number of adhered bacteria in the surface water of the Canal de Mira. Symbols: Bars: $\mathrm{NB}_{\mathrm{ad}}$ (number of adhered bacteria);

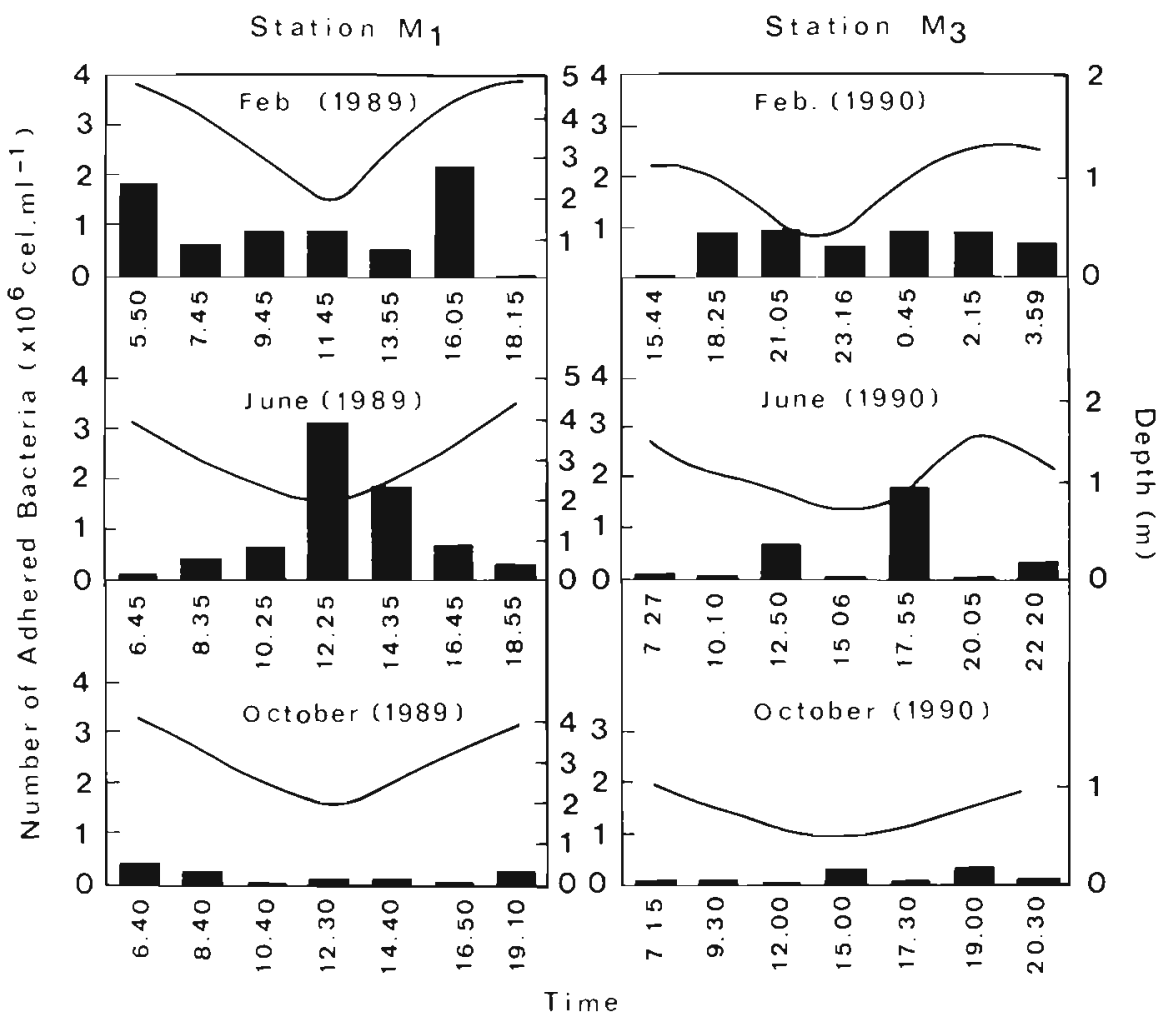


SURFACE WATER

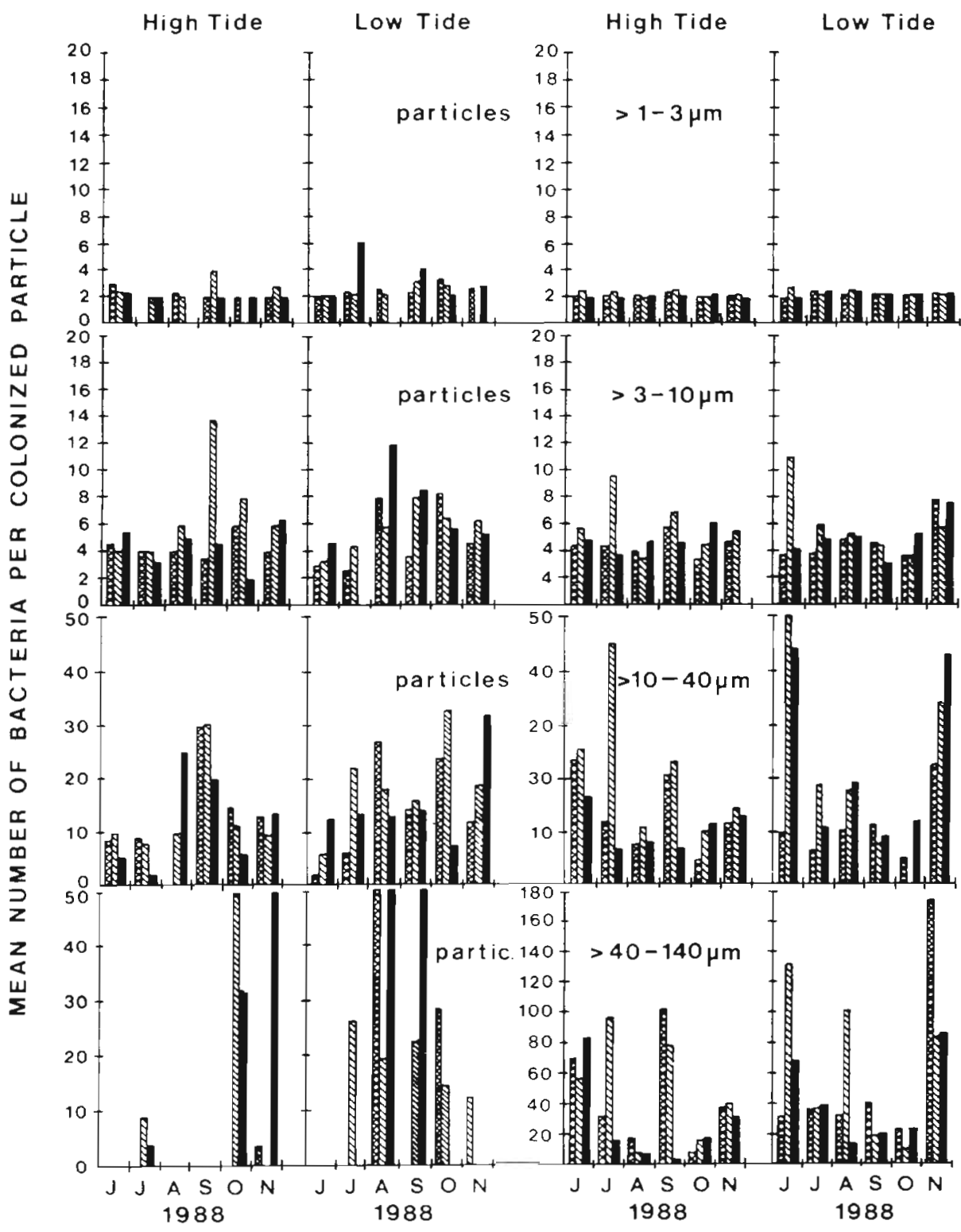

Fig. 4. Spatial and temporal variation of mean number of bacteria on colonized seston and sediment particles in the Cana de Mira. $\operatorname{Stn} \mathrm{M} 1 ;$ : $\mathrm{Stn} \mathrm{M} 2$ increased sucessively to factors of about 4, 14 and 24 in the following size-classes (Table 4). The increase in the variation of mean bacterial coverage did not reflect the variation in surface area within each particle size-class which corresponds to a factor of 9 in the first 2 classes and to factors of 16 and 12 in the third and fourth classes This suggests that bacterial colonization of large particles is more erratic than that of small ones.

Table 4. Bacterial coverage of colonized particles in the Canal de Mira (June to November 1988)

\begin{tabular}{|ccccc|}
\hline $\begin{array}{c}\text { Particle } \\
\text { size-class } \\
(\mu \mathrm{m})\end{array}$ & \multicolumn{4}{c|}{$\begin{array}{c}\text { Average number of bacteria per colonized particle (range) } \\
\text { Near-surface water }\end{array}$} \\
\hline$>1-3$ & $2(2.0-4.0)$ & $3(2.0-6.0)$ & High tide & Sediment \\
$>3-10$ & $5(2.0-13.7)$ & $6(2.7-12.0)$ & $2(2.0-2.5)$ & $2(2.0-2.7)$ \\
$>10-40$ & $13(2.0-30.5)$ & $16(2.0-33.0)$ & $5(3.4-9.6)$ & $5(3.0-11.0)$ \\
$>40-140$ & $45(4.0-150.0)$ & $59(12.0-192.0)$ & $15(5.0-45.1)$ & $21(5.2-79.9)$ \\
& & & $40(4.0-102.0)$ & $54(10.0-174.8)$ \\
\hline
\end{tabular}


Table 5. Contribution of bacteria on particles of different sizes to the total number of attached bacteria in surface water of the Canal de Mira (January 1989 to December 1990)

\begin{tabular}{|ccc|}
\hline $\begin{array}{c}\text { Particle } \\
\text { size-class } \\
(\mu \mathrm{m})\end{array}$ & $\begin{array}{c}\text { Fraction of all } \\
\text { colonized particles } \\
(\text { mean } \% \pm \mathrm{SD})\end{array}$ & $\begin{array}{c}\text { Fraction of total } \\
\text { adherent bacteria } \\
\text { (mean } \% \pm \mathrm{SD})\end{array}$ \\
\hline$>1-3$ & $18.9 \pm 9.4$ & $7.2 \pm 6.8$ \\
$>3-10$ & $55.7 \pm 8.5$ & $41.3 \pm 18.1$ \\
$>10-40$ & $24.4 \pm 10.7$ & $44.8 \pm 21.4$ \\
$>40-140$ & $1.0 \pm 1.2$ & $6.7 \pm 16.3$ \\
\hline
\end{tabular}

The importance of particle-size in the extent of bacterial colonization was assessed in 2 ways: through the relative frequency of each class of colonized particles (as percentage of total number of colonized particles) and through the index of relative particle coverage (I) which is a measure of the density of coverage. The index is the ratio (\%) of the observed and expected mean bacterial coverage, the expected mean being derived from mean number of bacteria on the smaller particles and surface-area ratios. In a total of 5532 colonized particles observed from January 1989 to December 1990, the most frequent were in the sizeclass $>3$ to $10 \mu \mathrm{m}$ in diameter, accounting for $55.7 \%$ of the total number of particles (Table 5). The less frequent $(1.0 \%)$ was the $>40$ to $140 \mu \mathrm{m}$ class. In spite

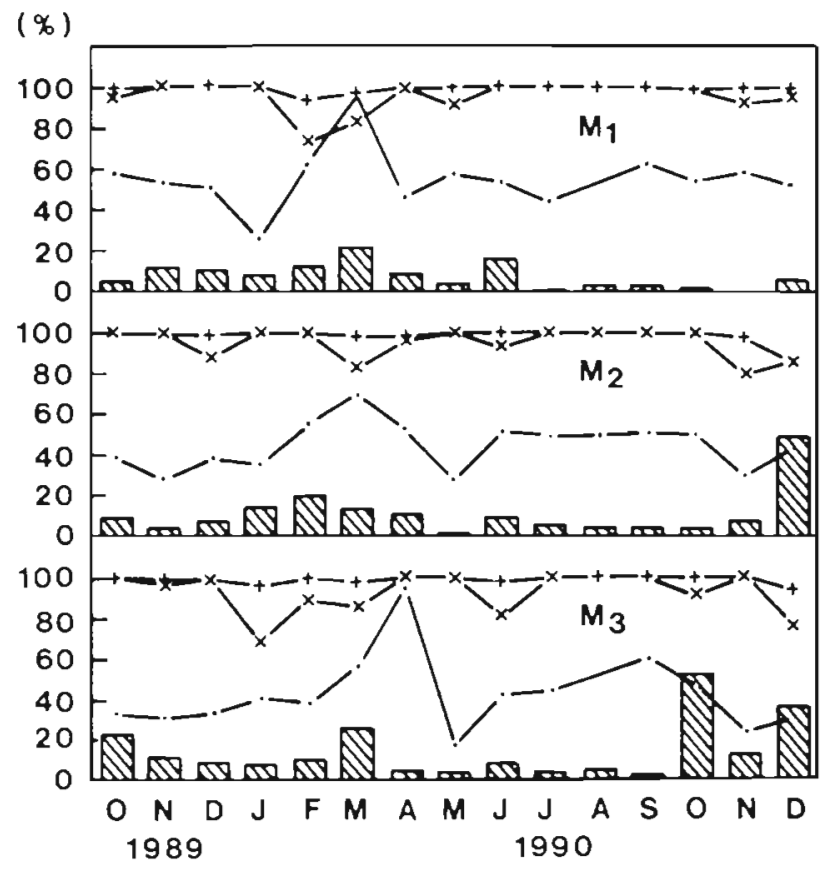

Fig. 5. Small particle frequency and colonization in surface water (Canal de Mira). - - - frequency of $>1$ to $40 \mu \mathrm{m}$ particles; + : contribution of particles $>1$ to $40 \mu \mathrm{m}$ to the total number of colonized particles; $x$ : contribution of $>1$ to $40 \mu \mathrm{m}$ particles to $\mathrm{NB}_{\text {ad; }} \mathrm{A}: \mathrm{NB}_{\mathrm{ad}}$
Table 6. Relative bacterial coverage of colonized particles in the surface water of the Canal de Mira (January 1989 to December 1990). SR: surface-area ratio; n: average number of bacteria observed per particle and standard deviation; $N$ : theoretical number of bacteria per particle derived from the observed mean colonization of the smaller particles and $\mathrm{SR}_{i} I$ : index of relative coverage $(I=100 \times \mathrm{n} / \mathrm{N})$

\begin{tabular}{|crccc|}
\hline $\begin{array}{c}\text { Particle } \\
\text { size-class }\end{array}$ & $\begin{array}{c}\text { Surface- } \\
\text { area } \\
\text { ratio } \\
(\mu \mathrm{m})\end{array}$ & $\begin{array}{c}\text { Observed } \\
\text { coloni- } \\
\text { zation } \\
(\mathrm{SR})\end{array}$ & $\begin{array}{c}\text { Derived } \\
\text { coloni- } \\
\text { zation } \\
(\mathrm{N})\end{array}$ & $\begin{array}{c}\text { Index of } \\
\text { relative } \\
\text { coverage }(\%) \\
(I)\end{array}$ \\
\hline$>1-3$ & 1 & $2.4 \pm 0.6$ & 2.4 & 100 \\
$>3-10$ & 11 & $5.9 \pm 3.3$ & 26.4 & 22 \\
$>10-40$ & 156 & $17.5 \pm 11.5$ & 374.4 & 5 \\
$>40-140$ & 2020 & $77.5 \pm 104.0$ & 4848.0 & 2 \\
\hline
\end{tabular}

of the large variation (20 to $90 \%$ ) in the relative frequency of the total (colonized and non-colonized) particles equal to or smaller than $40 \mu \mathrm{m}$, their contribution to $\mathrm{NB}_{\text {ad }}$ was always above $70 \%$ and their contribution to the number of colonized particles close to $100 \%$ (Fig. 5). The $I$ value decreased about 5 and 20 times within this size range (Table 6). These numbers, taken together, indicate that the efficiency of the bacterial process of colonization is inversely related to particle size.

\section{DISCUSSION}

In fresh and ocean waters $\mathrm{FB}_{\mathrm{ad}}$ is usually below $50 \%$ and frequently below $20 \%$ of total bacterial counts (Iriberri et al. 1987). In estuaries and salt marshes the attached state can be either rare (Zimmermann 1977), predominant (Goulder 1977) or of varying predominance depending on season (Wilson \& Stevenson 1980) or on salinity (Bell \& Albright 1981). In the Ria de Aveiro and the incoming water of the River Vouga, we found that, in spite of the contrasting hydrographical features of the 16 stations, only seldom was $\mathrm{FB}_{\text {ad }}$ above $20 \%$, with the 2 yr averages ranging from 5 to $16 \%$. The different environmental factors measured, some of which were previously associated with increased bacterial attachment in other water bodies, could not be linked to pronounced variation in the extent of colonization of seston particles in the Ria de Aveiro (Tables $1 \& 2$ ). These results agree with those of other authors (Zimmermann 1977, Yoon \& Rosson 1990). The average frequency of small particles $(>1$ to $40 \mu \mathrm{m})$ in the water of Stns M1 to M3 was $43 \%$ of total particles, implying that, here, suspended particles are generally larger than in the Humber Estuary (NE England) where that fraction was greater than $87 \%$ and where attached bacteria predominated (Goulder 1977). This 
may, however, not be relevant as our results do not show a direct relationship between $F B_{\text {ad }}$ values and frequency of $>1$ to $40 \mu \mathrm{m}$ particles (colonized plus noncolonized) as percentage of the total number of particles (Figs. 2 \& 5).

Wilson \& Stevenson (1980) and Yoon \& Rosson (1990) observed increased abundance of sestonic bacteria during ebbing and low tides. This increase was also observed in the Ria de Aveiro but was not a constant feature throughout the year (Fig. 3).

In the Ria de Aveiro, TBN commonly increases by a factor of 2 during spring and summer, the factor being larger (up to 5) in brackish inner waters than in stations near the mouth (Alcântara et al. 1991). FB ad tended, however, to decrease during the warmer months, although the temporal fluctuations did not show a regular pattern (Table 2), as was also noticed by Zimmermann (1977) and Iriberri et al. (1987) but contrasts with observations by Wilson \& Stevenson (1980) and Pedròs-Alio \& Brock (1983).

Attached bacteria were predominant in surface sediments which agrees with previous results reviewed by Rheinheimer (1981). In spite of a sharp increase of bacterial density in fine sediments, as observed by ZoBell (1938), the average value $(73 \%)$ of $\mathrm{FB}_{\mathrm{ad}}$ was roughly similar in sandy and silty deposits (Table 3 ).

The contribution of bacterial carbon and nitrogen to the diet of particle feeders has been a matter of controversy. Different authors emphasize selection by predators feeding on bacteria attached to detritus (Hanson \& Wiebe 1977), or the importance of bacteria-produced extracellular mucopolysaccharides (Hobbie \& Lee 1980), while others dispute a significant nutritious value of bacteria on particles (Allison \& Sutherland 1987). Nevertheless feeding on attached bacteria has been well established for some species of the nanoand microzooplankton (Sibbald \& Albright 1988). The relative extent of bacterial coverage of different particles has, then, direct implications on the flux of carbon and nitrogen to higher levels of the food web through detritivorous chains.

The efficiency (frequency and extent) of particle colonization can be envisaged as depending on 2 complex factors. First, bacterial adherence, a factor which may be related to particle abundance (Goulder 1977, Yoon \& Rosson 1990), particle quality or shape (DeFlaun \& Mayer 1983), water velocity and nature of the bacterial envelope. The efficiency of adherence would be expected to be reflected in the frequency of colonized particles. This is $\leq 50 \%$ in surface waters (Hanson \& Wiebe 1977, Iriberri et al. 1987). The fact that, irrespective of the abundance of seston and of its organic content at the 16 stations the $\mathrm{FB}_{\mathrm{ad}}$ value was constantly low (Tables $1 \& 2$ ) indicates that the bacterial capacity for adherence in the water of Ria de
Aveiro and River Vouga is generally low. From the lack of evidence for the involvment of relevant environmental factors on $\mathrm{FB}_{\mathrm{ad}}$ we conclude that this low capacity is probably an inherent property of planktonic bacteria, and that sestonic bacteria are mainly of sedimentary origin. This assumption is supported by the similarity of bacterial coverage in sediment and suspended particles on a per-particle-basis (Fig. 4, Table 4). It is also supported by the bias in bacterial colonization of small particles (>1 to $40 \mu \mathrm{m}$ ) irrespective of the relative frequency of particles in the water (Fig. 5).

The efficiency of the colonization process would also depend on the bacterial capacity for growth, that is, the rate of bacterial multiplication and spreading on the particle surface. Analysis of the extent of bacterial colonization of particles of different sizes revealed that the average number of bacteria per particle, in the size-range of $>1$ to $140 \mu \mathrm{m}$, varied from 2 to 192 . Colonized particles $\leq 40 \mu \mathrm{m}$ showed 2 to 80 bacterial cells, agreeing with results by Fergusson \& Rublee (1976) and Marsh \& Odum (1979), but contrasting with the values of 2.9 to 6.4 cells per particle obtained by Iriberri et al. (1987) in coastal waters. Considering the particles of the 4 size-classes that may be of interest to detritivorous species, ranging from ciliates (Albright et al. 1987) and heterotrophic flagellates (Sibbald \& Albright 1988) to bivalves (Edwards 1987), the index of relative particle coverage drops sharply to $2 \%$ in particles $>40$ to $140 \mu \mathrm{m}$, as shown in Table 6 . This decrease agrees with Kondratieff \& Simons (1985) and Edwards (1987) but is contrary to the results of Marsh \& Odum (1979) who found increased bacterial coverages in larger particles. If the index reflects bacterial growth capacity - the second complex factor proposed as governing the efficiency of colonization - it may be higher in small particles for several reasons: (1) smaller particles are more intensively grazed and nutrients liberated during grazing encourage bacterial growth (Morrison \& White 1980); (2) particle surfaces are conditioned by adherent bacteria through the production of mucopolysaccharides (Hobbie \& Lee 1980) which, tending to promote bacterial growth and to encompass a larger fraction of the surface area in the case of small particles, increases bacterial coverage; (3) particles tend to fracture along lines or areas of bacterial growth and enzymatic attack, originating small portions of denser colonization as well as sparsely colonized particle fractions of larger dimensions.

\section{CONCLUSION}

The similarity of bacterial coverage of seston and sediment particles of the same size-class, as well as the lack of association of the number of adhered bacteria 
$\left(\mathrm{NB}_{\mathrm{ad}}\right)$ and particle frequency in surface water, suggest that most of the suspended adhered bacteria have their origin in resuspension of the top layer of the sediments. Considering the higher density of bacterial coverage of small particles shown by the index of relative particle coverage, we suggest that particle size may play an indirect role on bacterial growth on particles.

Acknowledgements. We thank Dr Margarida Rebola, Faculty of Chemical Engineering at the University of Coimbra, for her help with the laser granulometer and Dr Fernando Nicolau for his assistance in the statistical analysis

\section{LITERATURE CITED}

Albright, L. J., Sherr, E. B., Sherr, B. F., Fallon, R. D. (1987). Grazing of ciliated protozoa on free and particle-attached bacteria. Mar. Ecol. Prog. Ser. 38: 125-129

Alcântara, F., Almeida, M. A., Pereira, M. G. (1991). Qualidade microbjológica da água da Ria de Aveiro (1989-1990). Relatório do Projecto POLAVEIRO. Universidade de Aveiro, Aveiro

Allison, D., Sutherland, I. (1987). The role of exopolysaccharides in adhesion of freshwater bacteria. J. gen. Microbiol. 133: 1319-1327

Bell, C. R., Albright, L. J. (1981). Attached and free-floating bacteria in the Fraser River Estuary, British Columbia, Canada. Mar. Ecol. Prog. Ser. 6: 317-327

Brown, D., Felton, P. (1985). Direct measurement of concentration and size for particles of different shapes using laser light diffraction. Chem. Eng. Res. Des. 63:125-132

DeFlaun, M., Mayer, L. (1983). Relationships between bacteria and grain surfaces in intertidal sediments. Limnol. Oceanogr. 28(5): 873-881

Edwards, R. R. (1987). Sestonic bacteria as a food source for filtering invertebrates in two southeastern blackwater rivers. Limnol. Oceanogr. 32(1): 221-234

Fergusson, R. L., Rublee, P. (1976). Contribution of bacteria to standing crop of coastal plankton. Limnol. Oceanogr. 21: $141-145$

Fisz, M. (1963). Probability theory and mathematical statistics. John Wiley and Sons, New York

Goulder, R. (1977). Attached and free bacteria in an estuary with abundant suspended solids. J appl. Bacteriol. 43: $399-405$

Hall, A. (1982). Water quality problems in Ria de Aveiro. In: Proc. of the seminar 'Actual problems of oceanography in Portugal', JNICT and NATO Marine Science Panel, Lisbon, 20-21 Nov. 1980. Centro de Edições e Artes Gráficas do Ministério da Reforma Administriva, Lisbon, p. 159-169

Hanson, R. B., Wiebe, W. J. (1977). Heterotrophic activity associated with particulate size fractions in a Spartina alterniflora salt-marsh estuary, Sapelo Island, Georgia, USA, and the continental shelf waters. Mar. Biol. 42: $321-330$

Harvey, R. W., Lion, L. W., Young, L. Y., Leckie, J. O. (1982). Enrichment and association of lead and bacteria at particulate surfaces in a salt-marsh surface layer. J. mar. Res. 40(4): 1201-1212

Hobbie, J. E., Daley, R, Jasper, S. (1977). Use of Nuclepore filters for counting bacteria by fluorescence microscopy. Appl. environ. Microbiol. 33(5):1225-1228

Hobbie, J. E., Lee, C. (1980). Microbial production of extra- cellular material: importance in benthic ecology. In: Tenore, K., Coull, B. (eds.) Marine benthic dynamics. University of South Carolina Press, Columbia, p. 341-346 Iriberri, J., Unanue, M., Barcina, I., Egea, L. (1987). Seasonal variation in population density and heterotrophic activity of attached and free-living bacteria in coastal waters. Appl. environ. Microbiol. 53(10): 2308-2314

Kondratieff, P. F., Simmons, G. M. Jr (1985). Microbial colonization of seston and free bacteria in an impound river. Hydrobiologia 128: 127-133

Loosdrecht, M. C., Lyklema, J., Norde, W., Zehender, A. (1990). Influence of interfaces on microbial activity. Microbiol. Rev. 54(1): 75-87

Lopez, G. R. (1980). The availability of microorganisms attached to sediment as food for some marine depositfeeding molluscs with notes on microbial detachment due to the crystalline style. In: Tenore, K., Coull, B. (eds.) Marine benthic dynamics. University of South Carolina Press, Columbia, p. 387-405

Marsh, D. H., Odum, W. E. (1979). Effect of suspension and sedimentation on the amount of microbial colonization of salt marsh microdetritus. Estuaries 2(3): $184-188$

Morrison, S. J., White, D. (1980). Effects of grazing by estuarine gammaridean amphipods on the microbiota of allochthonous detritus. Appl environ. Microbiol. 40(3): 659-671

Paerl, H. W. (1975). Microbial attachment to particles in marine and freshwater ecosystems. Microb. Ecol. 2: 73-83

Palumbo, A. V., Fergusson, R. L., Rublee, P. A. (1984). Size of suspended bacteria cells and association of heterotrophic activity with size fractions of particles in estuarine and coastal waters. Appl. environ. Microbiol. 48: 157-164

Pedròs-Alio, C., Brock, T. D. (1983). The importance of attachment to particles for planktonic bacteria. Arch. Hydrobiol. 98(3): $354-379$

Rebola, M., Rasteiro, M., Pita, F. (1988). Flocculation/ deflocculation studies of kaolin suspensions using LDS In: Soares, O. D. D., Almeida, S. P., Bernardo, L. M. (eds.) Proc. of the Conference 'Laser Technologies in Industry', Porto, 6-8 June 1988. SPIE Vol. 952. International Society for Optical Engineering, Washington, DC, p. 502-506

Rheinheimer, G. (1981). Investigations on the role of bacteria in the food web of the Western Baltic. Kieler Meersforsch. (Sonderh.) 5: 284-290

Rodier, J. (1971). Analyse chimique et physico-chimique de l'eau, $2^{\text {eme }}$ edn. Dunod, Paris

Sibbald, M., Albright, L. (1988). Aggregated and free bacteria as food sources for heterotrophic microflagellates. A.ppl. environ. Microbiol. 54(2): 613-616

Silva, F. C. (1989). Relatório FT. MC 5/87, Anexo II, Apêndices 9 a 14. Instituto Hidrográfico, Lisboa

Strickland, J., Parsons, T (1972). A practical handbook of seawater analysis. Bull. Fish. Res. Bd Can. 167

Wilson, D. J., Stevenson, L. H. (1980). The dynamics of the bacterial population associated with a salt marsh. J. exp. mar. Biol. Ecol. 48: 123-138

Yoon, W. B., Rosson, R. A. (1990). Improved method of ennumeration of attached bacteria for study of fluctuation in the abundance of attached and free-living bacteria in response to diel variation in seawater turbidity. Appl environ. Microbiol. 56(3): 595-600

Zimmermann, R. (1977). Estimation of bacterial number and biomass by epifluorescence microscopy. In: Rheinheimer, G. (ed.) Microbial ecology of a brackish water environment. Springer-Verlag, New York, p. 103-120

ZoBell, C. E. (1938). Studies on the bacterial flora of marine bottom sediments. J. sedim. Petrol. 8(1): 10-18 